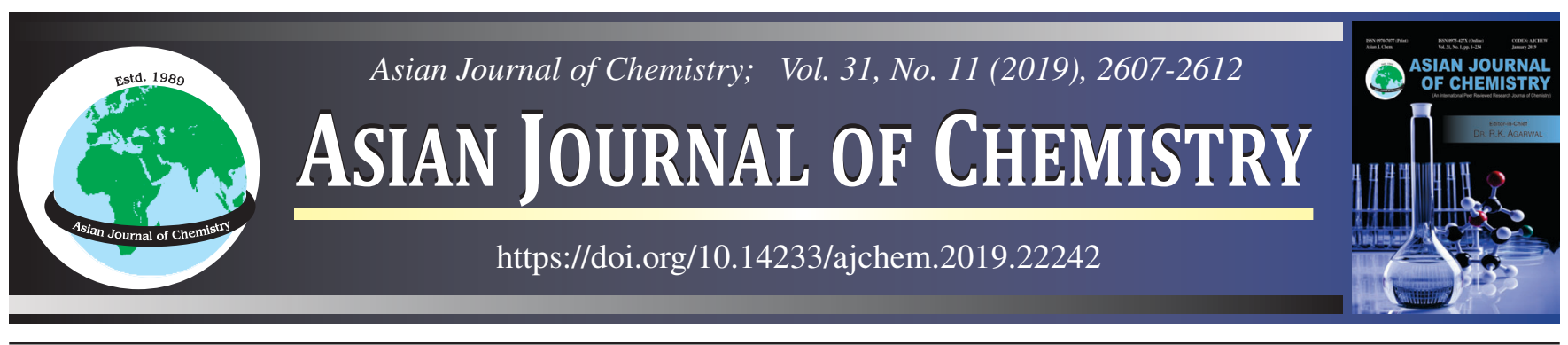

\title{
Synthesis and Antibacterial Activity of Novel Molybdenum Complexes with Macrocyclic Schiff Base Derived from Furanylethanedione
}

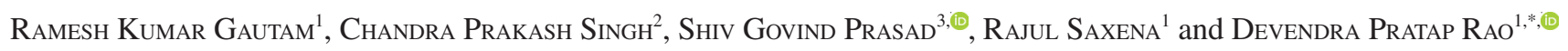

${ }^{1}$ Department of Chemistry, D.A.V. (P.G.) College, Kanpur-208001, India

${ }^{2}$ Department of Chemistry, D.B.S. (P.G.) College, Kanpur-208006, India

${ }^{3}$ Department of Chemistry, Uttar Pradesh Textile Technology Institute, Kanpur-208001, India

*Corresponding author: E-mail: devendraprataprao@yahoo.com

Received: 4 June 2019;

Accepted: 12 July 2019;

Published online: 28 September 2019;

AJC-19594

| A new $\mathrm{MoO}_{2}(\mathrm{VI})$ complex of formulation $\left[\mathrm{MoO}_{2}(\mathrm{~L})\right](\mathrm{acac})_{2}$ prepared by a Schiff base, synthesized via reaction of di-2-furanylethanedione with 5-chloropyridine-2,3-diamine and four new $\mathrm{MoO}_{2}(\mathrm{VI})$ complexes having formule $\left[\mathrm{MoO}_{2}(\mathrm{ML})\right](\mathrm{acac})_{2}$, derived from cyclization of $\left[\mathrm{MoO}_{2}(\mathrm{~L})\right](\mathrm{acac})_{2}$ with $\beta$-diketones are reported in this work. The synthesized $\mathrm{MoO}_{2}(\mathrm{VI})$ complexes were characterized on the basis of various analyses like thermal studies, UV-Vis, elemental analyses, NMR, IR and molar conductance. The coordination number of molybdenum metal is six. All the $\mathrm{MoO}_{2}(\mathrm{VI})$ complexes have distorted octahedral structure in which Mo atom is coordinated with two $\mathrm{O}$-atoms and four $\mathrm{N}$-atoms. All the complexes show moderate activity against S. typhi and S. aureus. Advancement in the antibacterial task is thought to be of chelation speculation.

Keywords: $\mathrm{MoO}_{2}(\mathrm{VI}), \boldsymbol{\beta}$-Diketones, Thermal study, Macrocyclic Schiff base.

\section{INTRODUCTION}

A macrocyclic complex is a cyclic complex which contains nine or more than nine (involving all hetero atoms) as well as three or more donor atoms. The coordination chemistry area of macrocyclic compounds has experienced amazing growth during the last 25 years [1-4]. A number of transition metals form stable complexes with Schiff bases. The complexes with Schiff base may models for organically important species. Complexes of transition metal with multidentated ligands of unexpected structure and coordination number have been evaluated [5]. Oxidation numbers of Mo varying from -2 to +6 . This is why molybdenum is flexible in nature [6]. The ability to arrangement of molybdenum complexes with N, O and Satom containing ligands prompted advancement of molybdenum complexes which are proficient catalysts in homogeneous and additionally in heterogeneous reactions [7-12].

$\mathrm{Mo}(\mathrm{VI})$ is present in aqueous medium as a straight forward $\left[\mathrm{MoO}_{4}\right]^{2-}$ ion depends upon on the $\mathrm{pH}$, concentration and of the medium. Oxygen transfer behaviour can show by molybdate ion agents [13]. Oxygen transfer activity of molybdate ion play a great role in the mechanism of molybdenum oxotransferase $[14,15]$. Molybdate ion is paramount in the quite oxidized conditions of many redox catalysts. In this case their dynamic sites comprise of a cis- $\mathrm{MoO}_{2}$ moiety [16-18].

Inside the second row of transition elements, only Mo is advised as bio-metal. Molybdenum is valuable for plants pathogenic, animal and human organisms [19,20]. Mo(VI) coordination chemistry is an important in research because of their enzymatic and organic interest [21-24]. Molybdenum established the physiologic actions of oxomolybdoenzymes [25-27]. Di-2furanylethanedione is an adaptable chelating agent and consist of two reactive-CO groups. Consequently, di-2-furanylethanedione has performed a mandatory aspect for the synthesis in macrocyclic ligands.

With above subject, few $\mathrm{MoO}_{2}$ (VI) compounds with polydenticity ligands will synthesize from reaction of di-2-furanylethanedione with diamine. The synthesized complex has capability of cyclization reaction with $\beta$-diketones through the template of metal. Keeping in view of the value of $\mathrm{MoO}_{2}$ (VI) ions in $\mathrm{O}$-atom exchange reactions and antibacterial routines, a fresh number of $\mathrm{MoO}_{2}$ (VI) macrocyclic complexes are actually

This is an open access journal, and articles are distributed under the terms of the Attribution 4.0 International (CC BY 4.0) License. This license lets others distribute, remix, tweak, and build upon your work, even commercially, as long as they credit the author for the original creation. You must give appropriate credit, provide a link to the license, and indicate if changes were made. 
synthesized. These complexes along with ligands have new denticity extracted from condensation of di-2-furanylethanedione with 5-chloropyridine-2,3-diamine effective at undergoing reaction with 1,3-diketones via the template effect of metal design have been formed.

\section{EXPERIMENTAL}

Reagent grade chemicals are used for the synthesis of Schiff base and their complexes. All the reagents and solvents were purchased from Aldrich and utilized without similarly purging, such as $\mathrm{MoO}_{2}(\mathrm{acac})_{2}$, 5-chloropyridine-2,3-diamine, di-2-furanylethanedione and 1,3-diketones (2,4-pentanedione, 1-phenyl-1,3butanedione, 4,4,4-trifluoro-1-(2-thienyl)-1,3-butanedione, and 1,3-diphenyl-1,3-propanedione).

$\mathrm{C}, \mathrm{H}, \mathrm{N}-$ Elemental analyses for the synthesized complexes were done at CRF, NERIST, Itanagar, India by using CHN analyzer. Nitrogen estimation for the prepared complexes was done by Kjeldahl's method. Molybdenum element estimated gravimetrically by regular method after decomposition of the molybdenum complex [28]. Estimation of S-element was done as $\mathrm{BaSO}_{4}$ [29]. Standard technique was used for determining uncorrected melting points with the help of sulfuric acid bath. The electronic absorption spectral measurements (ultravioletvisible spectra) for the formed $\mathrm{MoO}_{2}$ complexes were performed on Labinda-UV3000+ UV/VIS spectrophotometer in 1100 $220 \mathrm{~nm}$ range by using ethanol as solvent. IR absorption spectra of the synthesized $\mathrm{MoO}_{2}(\mathrm{VI})$ complexes over the 4000-400 $\mathrm{cm}^{-1}$ range were recorded in $\mathrm{KBr}$ on Perkin-Elmer Spectrum version 10.03.06 spectrophotometer. ${ }^{1} \mathrm{H}$ NMR spectra were acquired on JMM ECS-400 (JEOL) spectrometer with $400 \mathrm{MHz}$. Thermograph of parent complex $\left[\mathrm{MoO}_{2}(\mathrm{~L})\right](\mathrm{acac})_{2}$ was recorded under $\mathrm{N}_{2}$ atmosphere between $50-600{ }^{\circ} \mathrm{C}$ at the $10{ }^{\circ} \mathrm{C} \mathrm{min}{ }^{-1}$ heating rate through TG/DTA-Perkin Elmer, USA heat analyzers.

Synthesis of $\mathrm{MoO}_{2}(\mathrm{VI})$ complexes with Schiff base (L): The solution of molybdenyl acetylacetonate $(2.5 \mathrm{mmol}$, $0.81537 \mathrm{~g}$ ) in ethyl alcohol was added drop by drop to solution of di-2-furanylethanedione ( $2.5 \mathrm{mmol}, 0.4753 \mathrm{~g})$ and 5-chloropyridine-2,3-diamine ( $5 \mathrm{mmol}, 0.71785 \mathrm{~g}$ ) in ethyl alcohol $(50 \mathrm{~mL})$. The mixture was gently refluxed for $2 \mathrm{~h}$. The reaction mixture turned dirty yellow. The produced result filtered off and washed with ethyl alcohol. The solid product was isolated in vacuum in presence of silica gel. The progress of the reaction was followed by TLC until the reaction was completed. The yield of $\left[\mathrm{MoO}_{2}(\mathrm{~L})\right](\mathrm{acac})_{2}$ was $55 \%$ (type I).

Equimolar concentrations of different 1,3-diketones viz. 2,4-pentanedione, 1-phenyl-1,3-butanedione, 4,4,4-trifluoro1-(2-thienyl)-1,3-butanedione or 1,3-diphenyl-1,3-propanedione) and the obtained product (type 1) in ethyl alcohol refluxed for $2 \mathrm{~h}$. TLC was used for checking the purity of type (II) macrocyclic complexes.

The solution of type I poured in ethyl alcohol and again reacted with $1,3-\beta$-diketones in a ratio of $1: 1$ for $2 \mathrm{~h}$ to form macrocyclic products (type II). TLC was also used for checking the purity of type (II) macrocyclic complexes.

\section{Physical and analytical data}

Ligand (1): Yield: $72 \%$; m.p.: $90^{\circ} \mathrm{C}$; Anal. calcd. (found) $\%$ for $\mathrm{C}_{20} \mathrm{H}_{14} \mathrm{~N}_{6} \mathrm{O}_{2} \mathrm{Cl}_{2}$ (m.w. 441.27): C, 54.43 (54.40); H, 3.19
(3.22); $\mathrm{N}, 19.04$ (19.02); where $\mathrm{L}=$ ligand prepared by reaction of di-2-furanylethanedione with 5-chloropyridine-2,3-diamine $(1: 2)$.

$\left[\mathrm{MoO}_{2}(\mathbf{L})\right](\mathbf{a c a c})_{2}$ (2): Yield: $55 \%$; m.p.: $140{ }^{\circ} \mathrm{C}$; Anal. calcd. (found) $\%$ for $\mathrm{C}_{30} \mathrm{H}_{28} \mathrm{~N}_{6} \mathrm{O}_{8} \mathrm{Cl}_{2} \mathrm{Mo}$ (m.w. 767.43): C, 46.95 (46.92); H, 3.67 (3.65); N, 10.95 (10.97); Mo, 12.50 (12.49).

$\left[\mathbf{M o O}_{2}\left(\mathbf{M L}^{1}\right)\right]\left(\right.$ acac $_{2}(3)$ : Yield: $55 \%$; m.p.: $102{ }^{\circ} \mathrm{C}$; Anal. calcd. (found) $\%$ for $\mathrm{C}_{35} \mathrm{H}_{32} \mathrm{~N}_{6} \mathrm{O}_{8} \mathrm{Cl}_{2} \mathrm{Mo}$ (m.w. 831.52): $\mathrm{C}, 50.55$ (50.54); H, 3.87 (3.86); N, 10.10 (10.08); Mo, 11.53 (11.52); where $\mathrm{ML}^{1}=$ macrocyclic ligand prepared by the reaction of ligand (L) with 1,3-diketone-2,4-pentanedione.

$\left[\mathrm{MoO}_{2}\left(\mathbf{M L}^{2}\right)\right](\mathbf{a c a c})_{2}(\mathbf{4})$ : Yield: $65 \%$; m.p.: $128^{\circ} \mathrm{C}$; Anal. calcd. (found) $\%$ for $\mathrm{C}_{40} \mathrm{H}_{34} \mathrm{~N}_{6} \mathrm{O}_{8} \mathrm{Cl}_{2} \mathrm{Mo}$ (m.w. 893.59): C, 53.76 (53.75); H, 3.83 (3.83); N, 9.40 (9.41); Mo, 10.73 (10.72); where $\mathrm{ML}^{2}=$ macrocyclic ligand prepared by the reaction of ligand (L) with 1,3-diketone-1-phenyl-1,3-butanedione.

$\left[\mathrm{MoO}_{2}\left(\mathbf{M L}^{3}\right)\right](\mathbf{a c a c})_{2}(\mathbf{5})$ : Yield: $60 \%$; m.p.: $105^{\circ} \mathrm{C}$; Anal. calcd. (found) $\%$ for $\mathrm{C}_{38} \mathrm{H}_{29} \mathrm{~N}_{6} \mathrm{O}_{8} \mathrm{SCl}_{2} \mathrm{~F}_{3} \mathrm{Mo}$ (m.w. 953.59); ; Anal. calcd. (found) \% for C, 47.86 (47.85); H, 3.06 (3.05); N, 8.81 (8.81); S, 3.36 (3.36); Mo, 10.06 (10.05); where $\mathrm{ML}^{3}$ $=$ macrocyclic ligand prepared by the reaction of ligand $(\mathrm{L})$ with 1,3-diketone-4,4,4-trifluoro-1-(2-thienyl)-1,3-butanedione.

$\left[\mathbf{M o O}_{2}\left(\mathbf{M L}^{4}\right)\right](\mathbf{a c a c})_{2}(\mathbf{6})$ : Yield: $55 \%$; m.p.: $120^{\circ} \mathrm{C}$; Anal. calcd. (found) $\%$ for $\mathrm{C}_{45} \mathrm{H}_{36} \mathrm{~N}_{6} \mathrm{O}_{8} \mathrm{Cl}_{2} \mathrm{Mo}$ (m.w. 955.66): C, 56.55 (56.53); H, 3.79 (3.78); N, 8.79 (8.78); Mo, 10.03 (10.01); where $\mathrm{ML}^{4}=$ macrocyclic ligand prepared by the reaction of ligand (L) with 1,3-diketone-1,3-diphenyl-1,3-propanedione.

Antibacterial assay: The synthesized $\mathrm{MoO}_{2}(\mathrm{VI})$ complexes were evaluated for antibacterial properties in vitro across four bacterial stresses i.e. S. typhi, S. aureus, E. aerogene and B. subtilis making use of cup and diffusion method of agarwell [20-22]. Herein, doxycycline drug was taken as standard antibacterial agent. Bore holes of $6 \mathrm{~mm}$ in diameter had been burrow in the agar by making use of metallic trencher. The denseness of solution of all bacteria in every pit has been adjusted in order to $3 \times 10^{5} \mathrm{CFU} / \mathrm{mL}$. The standardized solution were developed upon the top of agar medium. The formed $\mathrm{MoO}_{2}(\mathrm{VI})$ complexes were mixed in $1 \%$ DMSO. Trial sample was contained $300 \mu \mathrm{g} \mathrm{mL}^{-1}$ concentration. The trial samples have been placed in the analogous wells. Rest wells had been engaged with doxycycline $(0.05 \%)$ antibacterial agent and DMSO. Growth restriction has been check out after $28 \mathrm{~h}$ incubation at $35^{\circ} \mathrm{C}$.

\section{RESULTS AND DISCUSSION}

Infrared analysis: The $\mathrm{MoO}_{2}(\mathrm{VI})$ complexes with Schiff base were prepared by the reaction of molybdenyl acetylacetonate, 5-chloropyridine-2,3-diamine and di-2-furanylethanedione in 1:2:1 ratio in ethyl alcohol. Essential infrared spectral bands of ligand. $\mathrm{MoO}_{2}(\mathrm{VI})$ complexes and their uncertain modes were showed in Table-1. $\mathrm{N}$-atoms of azomethine groups coordinated to Mo in all synthesized cyclic complex. It was evidenced by the lowering of $v(\mathrm{C}=\mathrm{N})$ frequencies [30-33]. The frequencies $1653-1651 \mathrm{~cm}^{-1}$ is assigned to stretching vibration of with $>\mathrm{C}=\mathrm{N}$ group absorption. These frequencies normally origins at $1680 \mathrm{~cm}^{-1}$ in ligands [30-32]. New infrared band about $468-466 \mathrm{~cm}^{-1}$ might be represented to $v(\mathrm{Mo}-\mathrm{N})$ vibration $[28,34]$, which is lacking in isolated ligands. Bonding of two 
TABLE-1

INFRARED SPECTRAL BANDS $\left(\mathrm{cm}^{-1}\right)$ OF LIGAND AND $\mathrm{MoO}_{2}(\mathrm{VI})$ COMPLEXES

\begin{tabular}{|c|c|c|c|c|c|c|c|c|}
\hline Complex & $v(\mathrm{C}=\mathrm{N})$ & $v(\mathrm{Mo}-\mathrm{N})$ & $\begin{array}{c}v(\mathrm{C}=\mathrm{O}) \text { of } \\
\text { acetylacetonate }\end{array}$ & $\begin{array}{c}v(\mathrm{C}=\mathrm{C}) \text { of } \\
\text { acetylacetonate }\end{array}$ & $\mathrm{v}_{\text {asym }}(\mathrm{O}=\mathrm{Mo}=\mathrm{O})$ & $v_{\text {sym }}(\mathrm{O}=\mathrm{Mo}=\mathrm{O})$ & $\begin{array}{c}v_{\text {asym }} \\
(\mathrm{N}-\mathrm{H})\end{array}$ & $\mathrm{v}_{\mathrm{sym}}(\mathrm{N}-\mathrm{H})$ \\
\hline $\mathrm{L}$ & $1646 s$ & - & - & - & - & - & $3356 \mathrm{~s}$ & $3180 \mathrm{~s}$ \\
\hline$\left[\mathrm{MoO}_{2}(\mathrm{~L})\right](\mathrm{acac})_{2}$ & $1653 \mathrm{~s}$ & $468 \mathrm{~m}$ & $1564 \mathrm{~s}$ & $1459 m$ & $903 \mathrm{~s}$ & $930 s$ & $3344 s$ & $3175 \mathrm{~s}$ \\
\hline$\left[\mathrm{MoO}_{2}\left(\mathrm{ML}^{1}\right)\right](\mathrm{acac})_{2}$ & $1645 \mathrm{~s}$ & $465 \mathrm{~s}$ & $1558 \mathrm{~m}$ & $1470 \mathrm{~m}$ & $901 \mathrm{~s}$ & $935 \mathrm{~s}$ & - & - \\
\hline$\left[\mathrm{MoO}_{2}\left(\mathrm{ML}^{2}\right)\right](\mathrm{acac})_{2}$ & $1651 \mathrm{~s}$ & $466 \mathrm{~m}$ & $1564 \mathrm{~s}$ & $1483 \mathrm{~m}$ & $903 \mathrm{~s}$ & $931 \mathrm{~s}$ & - & - \\
\hline$\left[\mathrm{MoO}_{2}\left(\mathrm{ML}^{3}\right)\right](\mathrm{acac})_{2}$ & $1655 \mathrm{~s}$ & $474 m$ & $1565 \mathrm{~s}$ & $1465 \mathrm{~m}$ & $905 \mathrm{~m}$ & $935 \mathrm{~m}$ & - & - \\
\hline$\left[\mathrm{MoO}_{2}\left(\mathrm{ML}^{4}\right)\right](\mathrm{acac})_{2}$ & $1650 \mathrm{~m}$ & $469 m$ & $1542 \mathrm{~m}$ & $1470 \mathrm{~m}$ & $900 \mathrm{~m}$ & $944 \mathrm{~s}$ & - & - \\
\hline
\end{tabular}

ketonic groups of di-2-furanylethanedione via $>\mathrm{C}=\mathrm{O}$ oxygen with diamines was evidenced through the presence of $>\mathrm{C}=\mathrm{N}$ band and the missing of $>\mathrm{C}=\mathrm{O}$ band near to $1710 \mathrm{~cm}^{-1}[35,36]$.

IR spectral bands of tetradentate ligand and as well as its dioxomolybdeum(VI) complexes are quite complicated due to the presence of various ring vibrations and $\mathrm{C}-\mathrm{H}$ vibrations. A wide band centered at $3356 \mathrm{~cm}^{-1}$ for $\mathrm{v}_{\text {asym }}(\mathrm{N}-\mathrm{H})$ and 3180 for $v_{\text {sym }}(\mathrm{N}-\mathrm{H})$. In the complex $\left[\mathrm{MoO}_{2}(\mathrm{~L})\right](\mathrm{acac})_{2}$ the two bands of primary amine appeared, but the second band is absent in complex $\left[\mathrm{MoO}_{2}(\mathrm{ML})\right](\mathrm{acac})_{2}$, which confirm the coordination of NH-with the metal [37]. This is because of high application of $d$-orbital for coordination. The $\mathrm{MoO}_{2}(\mathrm{VI})$ complexes offer two $\mathrm{Mo}=\mathrm{O}$ stretching bands at 903 and $931-930 \mathrm{~cm}^{-1}$. These bands occur due to two stretching vibrations. These bands include one asymmetric stretching vibration and other symmetric stretching vibration of $c i s-\left[\mathrm{MoO}_{2}\right]^{2+}$ moiety in $\mathrm{C}_{2 \mathrm{~V}}$ symmetry [38]. These bands are assigned to $v_{\text {asym }}(\mathrm{O}=\mathrm{M}=\mathrm{O})$ and $v_{\text {sym }}(\mathrm{O}=\mathrm{M}=\mathrm{O})$ vibrations, respectively [38-44]. The $\mathrm{v}_{\text {asym }}(\mathrm{O}=\mathrm{M}=\mathrm{O})$ vibrations are less than those of $v_{\text {sym }}(\mathrm{O}=\mathrm{M}=\mathrm{O})[45,46]$. The absorption bands present around $1483-1459$ and $1564-1540 \mathrm{~cm}^{-1}$ are assigned to $v(\mathrm{C}=\mathrm{C})$ and $v(\mathrm{C}=\mathrm{O})$ vibrations. These absorption bands confirmed the occurrence of $(\mathrm{acac})_{2}$ group present in outer sphere [47]. IR bands of the rest $\mathrm{MoO}_{2}(\mathrm{VI})$ complexes exhibited the matching pattern of absorption bands. Both N-H stretching (asymmetrical and symmetrical) modes of terminal $-\mathrm{NH}_{2}$ groups disappear. This is because of bonding of these $-\mathrm{NH}_{2}$ groups with $\mathrm{CO}$ group of 1,3-diketones in cyclization mechanism $[47,48]$.

${ }^{1}$ H NMR analysis: ${ }^{1} \mathrm{H}$ NMR spectra of ligand (L) and all the synthesized molybdenum complexes have been documented in DMSO- $d_{6} .{ }^{1} \mathrm{H}$ NMR spectrum of synthesized free ligand shows signal due to $\mathrm{NH}_{2}$ at $\delta 5.72$, which is also present in $\left[\mathrm{MoO}_{2}(\mathrm{~L})\right](\mathrm{acac})_{2}$ at $\delta 4.96$ but absent in other four macrocyclic complexes $\left[\mathrm{MoO}_{2}(\mathrm{ML})\right](\mathrm{acac})_{2}$ which suggest the cyclization by $\beta$-diketones (Table-2). The ten protons appear as multiplets within the range $\delta 6.80-7.24$ for the ligand and molybdenum complexes. The peaks around $\delta 7.24$ are assigned to protons of aromatic ring. ${ }^{1} \mathrm{H}$ NMR spectrum around $83.7-4.8$ assigned to $\mathrm{CH}_{2} \mathrm{~N}$ fragment. The appearance of these chemical shifts may be due to the formation of two types of azomethine that is involved in the formation of macrocyclic complex. The sharp signal found as a singlet at $\delta 2.98$ may be due to the water present in DMSO- $d_{6}$ sample used (Table-2).

UV-visible spectra: The ultraviolet-visible spectra of tetradentate tetraaza ligand and dixomolybdenum(VI) complexes were noted in ethanol. These electronic bands are construed according to reported vitality plan $[49,50]$. The spectra in the dioxomolybdenum(VI) complexes with tetradentate ligand are similar to be able to the other thereby suggesting a new uniform

\begin{tabular}{ccccc}
\hline \multicolumn{5}{c}{ TABLE-2 } \\
\\
$\begin{array}{c}{ }^{1} \mathrm{HNMR} \text { SPECTRAL DATA OF LIGAND AND } \\
\text { DIOXOMOLYBDENUM COMPLEXES }(\delta)\end{array}$ \\
\hline \multicolumn{1}{c}{ Complex } & $\mathrm{HC}-\mathrm{\delta r}$ & $\mathrm{N}-\mathrm{H}$ & $\mathrm{C}-\mathrm{H}_{3}$ & $\mathrm{C}-\mathrm{H}$ \\
\hline $\mathrm{L}$ & $7.2410 \mathrm{H}$ & $5.724 \mathrm{H}$ & - & - \\
{$\left[\mathrm{MoO}_{2}(\mathrm{~L})\right](\mathrm{acac})_{2}$} & $6.9510 \mathrm{H}$ & $4.724 \mathrm{H}$ & $2.4712 \mathrm{H}$ & $5.692 \mathrm{H}$ \\
{$\left[\mathrm{MoO}_{2}\left(\mathrm{ML}^{1}\right)\right](\mathrm{acac})_{2}$} & $7.1210 \mathrm{H}$ & - & $2.4512 \mathrm{H}$ & $5.662 \mathrm{H}$ \\
{$\left[\mathrm{MoO}_{2}\left(\mathrm{ML}^{2}\right)\right](\mathrm{acac})_{2}$} & $7.0510 \mathrm{H}$ & - & $2.5112 \mathrm{H}$ & $5.712 \mathrm{H}$ \\
{$\left[\mathrm{MoO}_{2}\left(\mathrm{ML}^{3}\right)\right](\mathrm{acac})_{2}$} & $6.8010 \mathrm{H}$ & - & $2.6912 \mathrm{H}$ & $5.652 \mathrm{H}$ \\
{$\left[\mathrm{MoO}_{2}\left(\mathrm{ML}^{4}\right)\right](\mathrm{acac})_{2}$} & $6.8910 \mathrm{H}$ & - & $2.6012 \mathrm{H}$ & $5.712 \mathrm{H}$ \\
\hline
\end{tabular}

structure for all. The absorption bands of genuine $d-d$ transition aren't expected to show up because Mo(VI) ion has no electron in $d$-orbital. Charge transfer transition was existed from atomic orbital of nitrogen to a molybdenum element $d$-orbital $[\mathrm{N}(\pi) \rightarrow d(\mathrm{Mo})]$. The bands for such transition can be assigned. The recorded ultraviolet-visible spectra are comparable of rest $\mathrm{MoO}_{2}(\mathrm{VI})$ complexes that contain nitrogen atoms as donor sites.

Intra-ligand transition and $\mathrm{n} \rightarrow \pi^{*} / \pi \rightarrow \pi^{*}$ transitions may occur in synthesized complexes. These transitions can be identified by powerful absorption bands in the ultraviolet region at $\sim 293 \mathrm{~nm}$ and at $\sim 330 \mathrm{~nm}$. A reasonably intensive band appeared in the area $\sim 380-390 \mathrm{~nm}$ is caused by $[\mathrm{N}(\pi)$ $\rightarrow d(\mathrm{Mo})]$. The transition ${ }^{2} \mathrm{~B}_{2} \rightarrow{ }^{2} \mathrm{~A}_{1}\left(\mathrm{~d}_{\mathrm{xy}} \rightarrow \mathrm{d}_{\mathrm{x}^{2}-\mathrm{y}^{2}}\right)$ is probably masked by the above bands. It may be designated for chargetransfer transition from ligand (highest occupied ligand molecular orbital) to metal (the lowest unoccupied molybdenum $d$-orbital) [51,52]. Energy level diagram for synthesized Mo(VI) complexes was applied given by Ballhausen-Gray. UV-visible spectra (Fig. 1) show an octahedral arrangement (distorted) for all Mo(VI) complexes [53].

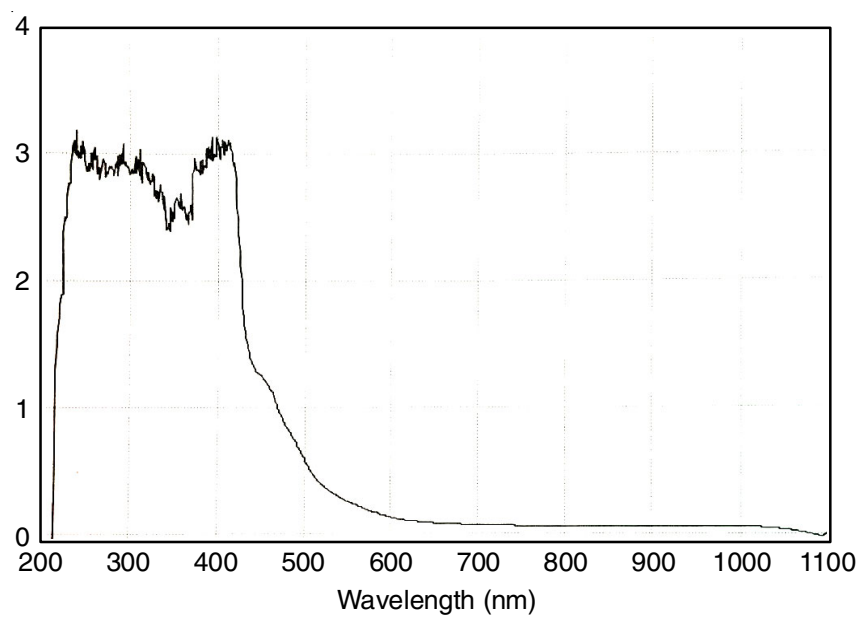

Fig. 1. UV spectrum of $\left[\mathrm{MoO}_{2}(\mathrm{~L})\right](\mathrm{acac})_{2}$ 
Conductivity and magnetic susceptibility: The complexes of $\mathrm{MoO}_{2}(\mathrm{VI})$ have $d^{0}$ configuration. Therefore, they are diamagnetic. The absence of electron in $d$-orbital of $\mathrm{MoO}_{2}(\mathrm{VI})$ results in no $d-d$ transitions. The 1:1 type electrolytes were proven by the molar conductance $\left(\Lambda_{\mathrm{M}}\right)$ merit for each of $\mathrm{MoO}_{2}(\mathrm{VI})$ complexes in DMF at about $10^{-3}$. The values of molar conductivity of these $\mathrm{MoO}_{2}$ (VI) complexes exist in the range 100-110 $\Omega^{-1} \mathrm{~cm}^{2} \mathrm{~mol}^{-1}$. Thus, the conductance values suggest the uncertain structures of type (I) $\mathrm{MoO}_{2}$ (VI) complexes and type (II) macrocyclic $\mathrm{MoO}_{2}(\mathrm{VI})$ complexes as presented in Schemes I and II.

Thermogravimetric analysis: Thermogravimetric analysis of $\left[\mathrm{MoO}_{2}(\mathrm{~L})\right](\mathrm{acac})_{2}$ complex was conducted in the heat range $50-600{ }^{\circ} \mathrm{C}$ with a $10^{\circ} \mathrm{C} \mathrm{min}{ }^{-1}$ temperature interval. No decomposition observed below $140^{\circ} \mathrm{C}$ (Fig. 2). The complex $\left[\mathrm{MoO}_{2}(\mathrm{~L})\right](\mathrm{acac})_{2}$ undergoes decomposition in two actions: (a) in first step, decomposition $\left(140-265^{\circ} \mathrm{C}\right)$ is due to the loss of ligand (obs. mass loss $55.50 \%$, calcd. $59.50 \%$ ) (b) in second step, the second gradual weight loss of at high temperature

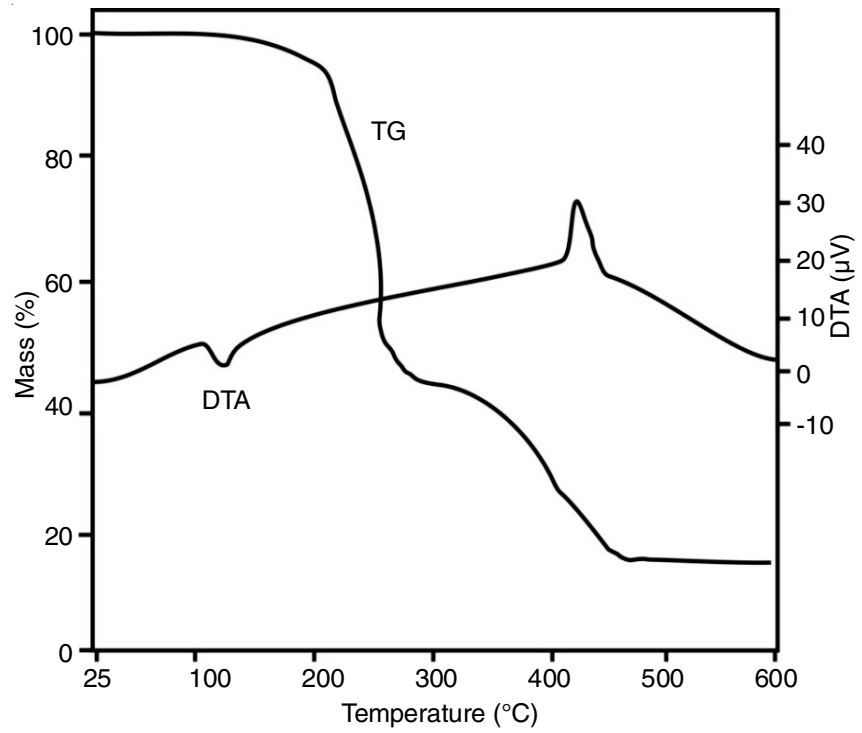

Fig. 2. TG and DTA thermographs of $\left[\mathrm{MoO}_{2}(\mathrm{~L})\right](\mathrm{acac})_{2}$

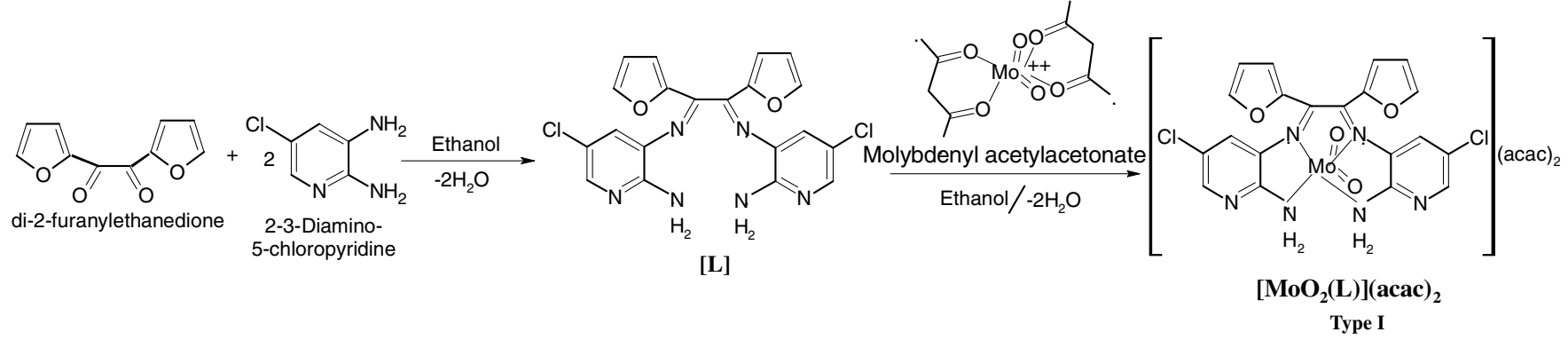

Scheme-I: Synthesis of $\left[\mathrm{MoO}_{2}(\mathrm{~L})\right](\mathrm{acac})_{2}$<smiles>Nc1ncc(Cl)cc1-n1c(=O)[nH]c2ncc(Cl)cc21</smiles>

$\left[\mathrm{MoO}_{2}(\mathrm{~L})\right](\mathbf{a c a c})_{2}$ Type I

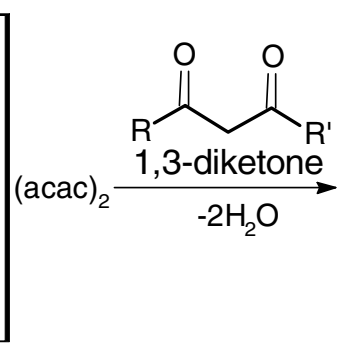

[

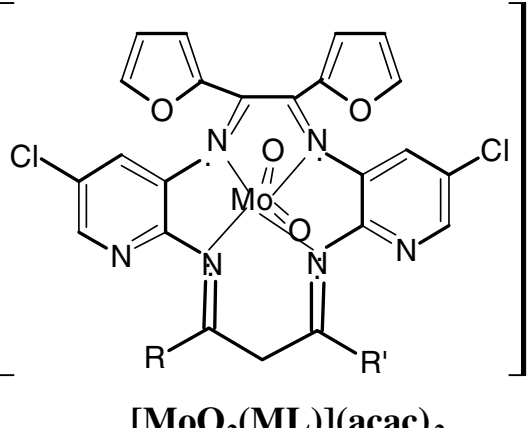

$\left[\mathrm{MoO}_{2}(\mathrm{ML})\right](\mathbf{a c a c})_{2}$

Type II

\begin{tabular}{ccccc}
\hline $\begin{array}{c}\text { Macrocyclic } \\
\text { complexes }\end{array}$ & $\mathrm{ML}^{1}$ & $\mathrm{ML}^{2}$ & $\begin{array}{c}\mathrm{R}=\mathrm{C}_{6} \mathrm{H}_{5} \\
\mathrm{R}^{\prime}=\mathrm{CH}_{3}\end{array}$ \\
\hline $\mathrm{R} \& \mathrm{R}^{\prime}$ & $\begin{array}{c}\mathrm{R}=\mathrm{CH}_{3} \\
\mathrm{R}^{\prime}=\mathrm{CH}_{3}\end{array}$ & $\begin{array}{c}\mathrm{R}=\mathrm{C}_{4} \mathrm{H}_{3} \mathrm{~S} \\
\mathrm{R}^{\prime}=\mathrm{CF}_{3}\end{array}$ \\
1,3-Diketones & & 2,4-Pentanedione
\end{tabular}

where, $\mathrm{L}=$ di-2-furanylethanedione + 5-chloropyridine-2,3-diamine; $\mathrm{ML}=$ Macrocyclic ligands carried out from condensation of $\mathrm{L}$ with 1,3-diketones in presence of dioxmolybdenum(VI) cation

Scheme-II: Synthesis of $\left[\mathrm{MoO}_{2}(\mathrm{ML})\right](\mathrm{acac})_{2}$ 


\begin{tabular}{|c|c|c|c|c|c|}
\hline \multicolumn{6}{|c|}{$\begin{array}{c}\text { TABLE-3 } \\
\text { ANTIBACTERIAL PROPERTIES OF MACROCYCLIC COMPLEXES OF } \mathrm{MoO}_{2}(\mathrm{VI})\end{array}$} \\
\hline Complex & S. aureus & E. aerogenes & S. typhi & B. subtilis & Doxycycline \\
\hline$\left[\mathrm{MoO}_{2}(\mathrm{~L})\right](\mathrm{acac})_{2}$ & 14 & 16 & 16 & 20 & 26 \\
\hline$\left[\mathrm{MoO}_{2}\left(\mathrm{ML}^{1}\right)\right](\mathrm{acac})_{2}$ & 16 & 19 & 17 & 18 & 25 \\
\hline$\left[\mathrm{MoO}_{2}\left(\mathrm{ML}^{2}\right)\right](\mathrm{acac})_{2}$ & 15 & 19 & 16 & -- & 25 \\
\hline$\left[\mathrm{MoO}_{2}\left(\mathrm{ML}^{3}\right)\right](\mathrm{acac})_{2}$ & 16 & 20 & 18 & 21 & 26 \\
\hline$\left[\mathrm{MoO}_{2}\left(\mathrm{ML}^{4}\right)\right](\mathrm{acac})_{2}$ & 17 & 16 & 17 & 22 & 23 \\
\hline
\end{tabular}

$\left(300-460^{\circ} \mathrm{C}\right)$ resulting in mass loss about $33 \%$ versus computed mass loss of $29 \%$. Finally, a precipitate obtained approximately be in agreement with $\mathrm{MoO}_{3}$ (obs. residual mass $=10.30 \%$, calcd. $=15.2 \%$ ) have already been kept after $460{ }^{\circ} \mathrm{C}$. Two peaks had been obtained in DTA curve. Endothermic decomposition as a result of melting of the complex $\left(140^{\circ} \mathrm{C}\right)$ can be seen by the first peak. The second peak is due to the exothermic effect. Near this exothermic peak in DTA curve, an exothermic bump had been also observed at $451.50{ }^{\circ} \mathrm{C}$. Residual mass obtained from exothermic decomposition in second step was proved by exothermic bump.

Antibacterial activity: The synthesized complexes of $\mathrm{MoO}_{2}$ (VI) had been analyzed against S. typhi, B. subtilis, $S$. aureus and $E$. aerogenes. Chelation principle was applied to explain the improvement in the antibacterial property of $\mathrm{MoO}_{2}(\mathrm{VI})$ complexes $[47,48]$. The growth inhibition showed in only two out of four bacteria namely Staphylococcus aureus and Salmonella typhi by all the $\mathrm{MoO}_{2}$ (VI) complexes (Table-3).

\section{Conclusion}

In this study, a basic pathways to form new $\mathrm{MoO}_{2}$ (VI) complexes with Schiff base is described. The spectroscopic methods have established the formation of Schiff base via reaction of di-2-furanylethanedione which is a flexible denticity ligand having two responsive $>\mathrm{C}=\mathrm{O}$ groups with diamines. Macrocyclic $\mathrm{MoO}_{2}$ (VI) complexes formed by cyclizations of parent complex with $\beta$-diketones. The geometry about molybdenum metal is octahedral (distorted). Dioxomolybdenum(VI) cation act as kinetic template. A significant action was created by kinetic template in the formation of Schiff base using di-2furanylethanedione and diamines in ethyl alcohol. Tetradentate tetraaza ligands behaviours were showed by formed Schiff bases. These Schiff bases coordinated towards molybdenum ion from the nitrogen atoms of azomethine. The analytical data confirmed the occurrence of one metal ion per ligand. Synthesized $\mathrm{cis}$ $\mathrm{MoO}_{2}(\mathrm{VI})$ complexes have mononuclear six coordination sphere. Distort octahedral geometry happen to be recommended for these $c i s-\mathrm{MoO}_{2}(\mathrm{VI})$ complexes.

\section{CONFLICT OF INTEREST}

The authors declare that there is no conflict of interests regarding the publication of this article.

\section{REFERENCES}

1. M.D.S. Healy and A.J. Rest, Adv. Inorg. Chem. Radiochem., 21, 1 (1978); https://doi.org/10.1016/S0065-2792(08)60277-0.

2. G.A. Melson, Coordination Chemistry of Macrocyclic Compounds, Plenum Press: NY (1979).

3. L.F. Lindoy and D.H. Busch, Prep. Inorg. React., 6, 1 (1971).

4. L.F. Lindoy and D.H. Busch, Inorg. Chem., 13, 2494 (1974); https://doi.org/10.1021/ic50140a037.
5. H.D.S. Yadava, S.K. Sengupta and S.C. Tripathi, Inorg. Chim. Acta, 128, 1 (1987);

https://doi.org/10.1016/S0020-1693(00)84685-X

6. D.C. Crans, Pure Appl. Chem., 77, 1497 (2005); https://doi.org/10.1351/pac200577091497.

7. M. Bagherzadeh, R. Latifi, L. Tahsini, V. Amani, A. Ellern and L.K. Woo, Polyhedron, 28, 2517 (2009);

https://doi.org/10.1016/j.poly.2009.05.036.

8. Z. Moradi-Shoeili, M. Zare, M. Bagherzadeh, M. Kubicki and D.M. Boghaei, J. Coord. Chem., 68, 548 (2015); https://doi.org/10.1080/00958972.2014.993321.

9. M. Bagherzadeh, M. Amini, H. Parastar, M. Jalali-Heravi, A. Ellern and L.K. Woo, Inorg. Chem. Commun., 20, 86 (2012); https://doi.org/10.1016/j.inoche.2012.02.023.

10. A.A.A. Aziz, J. Mol. Struct., 979, 77 (2010); https://doi.org/10.1016/j.molstruc.2010.06.004.

11. R.D. Chakravarthy, K. Suresh, V. Ramkumar and D.K. Chand, Inorg. Chim. Acta, 376, 57 (2011); https://doi.org/10.1016/j.ica.2011.05.033.

12. S. Rayati, N. Rafiee and A. Wojtczak, Inorg. Chim. Acta, 386, 27 (2012); https://doi.org/10.1016/j.ica.2012.02.005.

13. M.J. Pushie and G.N. George, Coord. Chem. Rev., 255, 1055 (2011); https://doi.org/10.1016/j.ccr.2011.01.056.

14. C.P. Rao, A. Sreedhara, P.V. Rao, M.B. Verghese, E. Kolehmainen, K. Rissanen, N.K. Lokanath, M.A. Sridhar and J.S. Prasad, J. Chem. Soc., 14, 2383 (1998); https://doi.org/10.1039/A801226A.

15. R. Hahn, W.A. Herrmann, G.R.J. Artus and M. Kleine, Polyhedron, 14, 2953 (1995); https://doi.org/10.1016/0277-5387(95)00133-D.

16. R.R. Mendel and F. Bittner, Biochim. Biophys. Acta-Mol. Cell Res., 1763, 621 (2006); https://doi.org/10.1016/j.bbamcr.2006.03.013.

17. A. Sigel and H. Sigel, Metal Ions in Biological Systems, Molybdenum and Tungsten: Their Roles in Biological Processes, Marcel Dekker, NY, p. 39 (2002).

18. R.C. Maurya, B. Shukla and A. Pandey, Indian J. Chem., 41A, 554 (2002).

19. I. Rousso, N. Friedman, M. Sheves and M. Ottolenghi, Biochemistry, 34, 12059 (1995); https://doi.org/10.1021/bi00037a049.

20. T. Baasov and M. Sheves, Biochemistry, 25, 5249 (1980); https://doi.org/10.1021/bi00366a040.

21. H. Mimoun, I. Seree de Roch and L. Sajus, Tetrahedron, 26, 37 (1970); https://doi.org/10.1016/0040-4020(70)85005-0.

22. V. Cont and F.D. Furia, Catalytic Oxidations with Hydrogen Peroxide as Oxidant, Kluwer Academic Publisher: Berlin (1992).

23. H. Mimoun, L. Saussine, E. Daire, M. Postel, J. Fischer and R. Weiss, J. Am. Chem. Soc., 105, 3101 (1983); https://doi.org/10.1021/ja00348a025.

24. M.L.H. Nair and D. Thankamani, Indian J. Chem., 48A, 1212 (2009).

25. G.D. Garner, ed.: G. Wilkinson, Molybdenum, Special Topics in Comprehensive Coordination Chemistry, Pergamon Press: Oxford, vol. 6, $1421((1987)$

26. M. Salavati-Niasari, F. Davar and M. Bazarganipour, Dalton Trans., 39, 7330 (2010); https://doi.org/10.1039/b923416k.

27. K. Ambroziak, R. Mbeleck, Y. He, B. Saha and D.C. Sherrington, Ind. Eng. Chem. Res., 48, 3293 (2009); https://doi.org/10.1021/ie801171s.

28. A.I. Vogel, A Textbook of Quantitative Inorganic Analysis, Longmans Green Co. Ltd., London, edn 4 (1978). 
29. A.I. Vogel, A Textbook of Practical Organic Chemistry, Longmans Green Co. Ltd.: London, edn 4 (1978).

30. V.B. Rana, P. Singh, D.P. Singh and M.P. Teotia, Transition Met. Chem., 7, 174 (1982); https://doi.org/10.1007/BF01035836.

31. S. Chandra and K.K. Sharma, Transition Met. Chem., 8, 1 (1983); https://doi.org/10.1007/BF00618784.

32. W.U. Malik, R. Bembi, R. Singh, S.P. Taneja and D. Raj, Inorg. Chim. Acta, 68, 223 (1983); https://doi.org/10.1016/S0020-1693(00)88965-3.

33. T. G⿳owiak, L. Jerzykiewicz, J.M. Sobczak and J.J. Ziólkowski, Inorg. Chim. Acta, 356, 387 (2003); https://doi.org/10.1016/S0020-1693(03)00301-3.

34. J.R. Ferraro, Low Frequency Vibrations of Inorganic and Coordination Compounds, Plenum: New York (1971).

35. J.R. Dyer, Applications of Absorption Spectroscopy of Organic Compounds, Prentice-Hall, Inc.: Englewood Cliffs, NJ (1965).

36. S. Singh, D.P. Rao, A.K. Yadava and H.S. Yadav, Curr. Res. Chem., 3, 106 (2011); https://doi.org/10.3923/crc.2011.106.113.

37. L.J. Willis, T.M. Loehr, K.F. Miller, A.E. Bruce and E.I. Stiefel, Inorg. Chem., 25, 4289 (1986); https://doi.org/10.1021/ic00243a045.

38. B.I. Ceylan, Y.D. Kurt and B. Ulkuseven, J. Coord. Chem., 62, 757 (2009); https://doi.org/10.1080/00958970802339669.

39. S.N. Rao, K.N. Munshi, N.N. Rao, M.M. Bhadbhade and E. Suresh, Polyhedron, 18, 2491 (1999); https://doi.org/10.1016/S0277-5387(99)00139-4.

40. S.M. El-Medani, M.M. Aboaly, H.H. Abdalla and R.M. Ramadan, Spectrosc. Lett., 37, 619 (2004); https://doi.org/10.1081/SL-200037610.

41. X.W. Zhu, Acta Chim. Slov., 65, 939 (2018); https://doi.org/10.17344/acsi.2018.4607.
42. R.C. Maurya, R. Verma and T. Singh, Synth. React. Inorg. Met.-Org. Chem., 33, 309 (2003); https://doi.org/10.1081/SIM-120017789.

43. X. Wang, X.M. Zhang and H.X. Liu, J. Coord. Chem., 33, 223 (1994); https://doi.org/10.1080/00958979408024280.

44. D.P. Rao, H.S. Yadav, A.K. Yadava, S. Singh and U.S. Yadav, E-J. Chem., 9, 497 (2012); https://doi.org/10.1155/2012/205123.

45. F.A. Cotton, G. Wilkinson, C.A. Murillo and M. Bochmann, Advanced Inorganic Chemistry, Wiley: New York, edn 6, vol. 18, p. 944 (1999).

46. K. Nakamoto K, "IR and Raman Spectra of Inorganic and coordination Compound, Part A and B" John Wiley \& Sons: New York (1998).

47. H. Gehrke Jr. and J. Veal, Inorg. Chim. Acta, 3, 623 (1969); https://doi.org/10.1016/S0020-1693(00)92563-5.

48. H.S. Yadav, Polyhedron, 12, 313 (1993); https://doi.org/10.1016/S0277-5387(00)81729-5.

49. D.P. Rao, H.S. Yadav, A.K. Yadava, S. Singh and U.S. Yadav, J. Coord. Chem., 64, 293 (2011); https://doi.org/10.1080/00958972.2010.544037.

50. K. Sakata, M. Kuroda, S. Yanagida and M. Hashimoto, Inorg. Chim. Acta, 156, 107 (1989); https://doi.org/10.1016/S0020-1693(00)90375-X.

51. R. Garg, M.K. Saini, N. Fahmi and R.V. Singh, Transition Met. Chem., 31, 362 (2006); https://doi.org/10.1007/s11243-005-0001-1.

52. E. Kahrovic, K. Molcanov, L. Tušek-Bozic and B. Kojic-Prodic, Polyhedron, 25, 2459 (2006); https://doi.org/10.1016/j.poly.2006.02.008.

53. C.J. Ballhausen and H.B. Gray, Inorg. Chem., 1, 111 (1962); https://doi.org/10.1021/ic50001a022. 